\title{
Nursing immersion learning experience in Amish country: finding the truth behind the image
}

\section{Editorial}

Driving through Ohio's farmland to meet my students, I felt a calm simplicity. Bright white laundry swung in the breeze. Corn was as it should be- knee high by the fourth of July. Women in their clean, simple, self-made dresses wore their plain, solid colors pinned or buttoned closed. Their faces were scrubbed clean of makeup. Hair pulled up snug under their tell-tale white bonnets.

The men I imagined to be sweltering under their straw, brimmed hats and their signature beards. They barely noticed as I pass their horse and buggy, clomping down the road, tapping out Amish Country's heartbeat. Being in this land time forgot, or at least has given a reprieve, seemed calming during the drive, until my mechanized GPS navigator told me to turn.

It's no secret that Amish Country is filled with simply, private, religious folks whose customs seem odd to us. That's why countless books, TV shows and movies have sought to depict the lifestyle.

So when I decided to give my students an immersion experience at an Amish birthing center, I expected a shy, private, religious people having babies in whitewashed homes on perfectly manicured, solid wood floors. What I didn't expect was an open, honest and unreserved dialogue - willing to answer the most detailed and private questions with which we "Yankees" struggle.

I had my perceptions immediately broken when I found the birthing center. It was a simple enough building. But it was brick. No whitewashing. The only sign was a hand painted piece of barn wood that was hammered into the ground bearing a single word: Buggies.

The center's director there was a "Yankee". She wore her hair down, jewelry, a knee length skirt without hose, and open toe sandals. Coincidentally, she drove the same car I do. But she didn't need a mechanized voice to guide her through Amish Country anymore.

That's what happens when you find your calling. And what a calling it is. Birthing children - the most basic of human functions - operates so differently a mere 25 miles from the world-class, $21^{\text {st }}$ Century hospital where I managed mother-baby units for several years prior to teaching. The Amish birthing center has a c-section rate of $0 \%$. They do not provide epidural anesthesia. They do not generally use Pitocin. They do not use continuous fetal monitoring. And yet they have healthy mothers and babies.

The students and I were mesmerized by stepping into their private and quiet world that treats the place where their women become mothers as sacred. Even the clothes seem sacred - crisp, white hospital gowns, dresses - not one sies - for the babies. The delivery rooms were very simple. They had a traditional bathroom and shower, bed, and in a nod to modern healthcare - a Doppler (for fetal heart tones) at the bedside.

Immediately, though, we learned to not mistake their reverence and solemnity toward birth with privacy about it. We discovered that nothing was off limits, even all of those questions we have, but feel inappropriate to ask. Nothing was off limits during our visit. We were
Volume 7 Issue 2 - 2017

Melissa Dyer
Associate Lecturer, Parent Newborn Nursing, USA

Correspondence: Melissa Dyer, Associate Lecturer, Parent Newborn Nursing, Health Care Policy and Delivery Systems, Kent State University, USA, Email mbmcgowa@kent.edu

Received: August 01, 2017| Published: August 18, 2017

in their simple space, asking questions that were anything but simple. Students' questions included ones about labor induction, pain control, teen sex, genetic anomalies, birth control, pregnancy termination, dating, courtship practices, sexual assault, violence, drug abuse, rationale for seeking care in traditional settings, and paying for care.

Marrying within the Amish community is an expectation. With this brings many questions for many of my college-aged students. We learned about bundling- a time when a boy and girl are encouraged to spend time in bed together (clothed) behind closed doors to bond as a part of courting. Sex education is not discussed. Birth control is not discussed and its use is discouraged, even for married couples who have many children.

They do not often show affection in public. However, during labor and delivery, that affection is clear and obvious. During my time as a floor nurse and instructor, my experience with Amish births has allowed me to witness some of the most extreme genetic anomalies possible - the result of the Amish community insisting on intrareligion marriages - a fact of Amish life that the folks at the birthing center addressed frankly and directly.

As far as health care delivery is concerned, the Amish do not use insurance. Rather, the community helps one another. The birthing center is funded largely by an annual auction. Patients are asked to pay a bit over $\$ 1,000$ for their labor, delivery, and post partum care, compared with the $\$ 10,000$ price tag on a traditional hospital bill.

We found that some Amish break the rules, use birth control, get pregnant as teens, and terminate pregnancies. Often, these practices are not discussed. Rather, these women are shunned. In many ways, this is similar to our customs.

I was proud of my students. I've found that these immersion experiences in labor and delivery and obstetrics provide a unique opportunity to look into a culture at its most foundational. My students' gawking was out of immense interest and intrigue. Students were seeking similarities and rationale for differences between the worlds. What an experience for reflecting on our own values and beliefs- graying the lines of what we thought we held sacred. 
What can nurses do to help the Amish and other cultures when we have the privilege of briefly entering their world?

All questions were answered.

Without hesitation.

As my students and I returned home in our horseless carriages, guided by satellites floating through space, I realized something.
Never again will we confuse plain exteriors for simple interiors.

\section{Acknowledgements}

None.

\section{Conflict of interest}

The author declares no conflict of interest. 